\title{
IMPACT OF CLIMATE CHANGE ON THE RUNOFF REGIME OF AN EASTERN HIMALAYAN RIVER BASIN
}

\section{SARKAR A.}

Received: $11 / 11 / 2014$

Accepted: 22/04/2015

Available online: $13 / 05 / 2015$

National Institute of Hydrology, Roorkee-247667, Uttarakhand, India

*to whom all correspondence should be addressed: e-mail: archana_sarkar@yahoo.com

\section{ABSTRACT}

The present study has been carried out for the trans-boundary Subansiri sub-basin of Brahmaputra river basin. Subansiri is the largest tributary of Brahmaputra within India and the river system has its practical importance as it holds a high water resources as well as hydropower potential for the country, which still remains highly under-developed. The probable impact of climate change has been analyzed using hypothetical climate scenarios to understand the behavior of total streamflow as well as snowmelt runoff under the changing conditions. Based on the simulations of a daily snowmelt runoff model (SNOWMOD) using six years of data, it has been observed that the total stream flow as well as the snowmelt runoff increase with temperature. Snowmelt runoff was found to increase by about $5 \%$ and $12 \%$ for the increase of $1{ }^{\circ} \mathrm{C}$ and $2{ }^{\circ} \mathrm{C}$ in temperature respectively. However, not much change in snowmelt runoff was observed with changed precipitation scenarios. It has been found from this study that total stream flow changes in all scenarios of temperature $(\mathrm{T})$ and precipitation $(\mathrm{P})$. The observed maximum $\%$ increase in mean annual stream flow was about $6 \%$ for the $\mathrm{T}+2^{\circ} \mathrm{C} \& \mathrm{P}+10 \%$ scenario and the minimum $\%$ decrease in mean annual stream flow observed was about $11 \%$ for $\mathrm{T}+1^{\circ} \mathrm{C} \& \mathrm{P}-10 \%$ scenario. The present study aims to provide information for planning of climate change adaptation strategies for the Subansiri sub-basin of the Brahmaputra River.

Keywords: Snowmelt runoff modelling, MODIS snowcover, Subansiri river basin, climate change

\section{Introduction}

Impact of climate change poses a high threat to the water resources of the globe. In tropical Asia, the affect of climate on hydrology has many facets. The Himalayas act as a mountain barrier on the earth and play an important role in maintaining and controlling the Asian monsoon system because of the interaction of polar, tropical and Mediterranean influences (Borgaonkar and Pant, 2001). The Himalayas are also known as the Asian water towers as they store large amount of freshwater in the form of snow and ice (in glaciers). Rivers originating from the Himalayas have their upper catchments in snow-covered areas and flow through steep terrain. Any change in the climatic conditions of the Himalayas has far going impact in the areas downstream. The Himalayan Rivers have displayed significant variations in stream flow, particularly the eastern Himalayan Rivers, where seasonal flows and monsoon flows (onset, peak and recession) showed huge changes in the recent past. It is assumed that sea-surface temperature (SST) and atmospheric circulation system cause these changes, however, the alterations in the timing and rate of snowmelt are assumed to be a result of changing temperatures in the Himalayan region. In the light of these changes, it is expected that water resources of the eastern Himalayan region are likely to undergo significant alterations in future. 
Recent rise in global mean air and ocean temperatures, extensive melting of snow and ice, and rising global average sea levels are indicators of climate change and global warming. In the last century, historical data analyses have illustrated an overall rise in global surface air temperature by about $0.5^{\circ} \mathrm{C}-$ $1.1^{\circ} \mathrm{C}$. The analysis of historical global surface temperature data since 1850 has also revealed that eleven of the recent twelve years (1995-2006) rank among the warmest years (IPCC, 2007). As per the recent IPCC report (AR5), the globally averaged combined land and ocean surface temperature data as calculated by a linear trend, show a warming of $0.85^{\circ} \mathrm{C}\left(0.65{ }^{\circ} \mathrm{C}\right.$ to $\left.1.06{ }^{\circ} \mathrm{C}\right)$, over the period 1880 to 2012 , when multiple independently produced datasets exist. The total increase between the average of the 18501900 period and the $2003-2012$ period is $0.78{ }^{\circ} \mathrm{C}\left(0.72{ }^{\circ} \mathrm{C}\right.$ to $0.85^{\circ} \mathrm{C}$, based on the single longest dataset available (IPCC, 2013). Over the last 50 years, changes in global extreme temperatures have been widespread, the rate of which is almost double to that over the last 100 years. At global, regional and ocean basin scales, numerous long-term changes in other climatic variables have also been observed which include widespread changes in the rainfall, wind patterns, various facets of extreme weather (intense rainfall, intensity of tropical cyclones, heat waves, droughts). During the past four decades, hemispheric snow cover area (SCA) in most of the regions has also shown a decline, particularly during spring and summer (IPCC, 2007). Dye (2002), has reported in his study using historical climate data for a period of 1972-2000 that there has been statistically significant reduction in annual mean SCA; the SCA which used to reach its maximum spread in the month of February shifted to occur during January which subsequently lead to an advancement of snowmelt towards earlier spring by almost two weeks. Significant variations in the response of hydrological systems in terms of erosion processes and sedimentation are also expected due to the impending climate change as observed in the Brahmaputra river basin (Sarkar, 2013).

With global climate change posing a threat to the water resources, it is very much required to carry out an evaluation of future water availability at various temporal and spatial scales. An understanding of the hydrological response of a river basin under changing climatic conditions is required for better management of floods and low flows and revision of water allocation policies for different sectors such as domestic, agriculture, industry, hydropower generation etc. The water flowing in the Himalayan Rivers is the combined drainage from rainfall, snowmelt and glacier-melt runoff. Various studies have pointed towards an overall consistent warming trend in the Himalayan region, including the Tibetan Plateau (Borgaonkar and Pant, 2001; Caesar et al., 2006). As the Himalayan water system is highly dependent on snow storage, it is susceptible to suffer from the effects of global warming. The understanding of climate change has improved significantly through improvements and extensions of numerous datasets and more sophisticated data analyses across the globe. However, in the rivers of eastern Himalayan region, not many scientific interventions on climate change and its impact on hydrology have been made mainly due to their trans-boundary nature, inaccessible upper basins, highly steep terrain and inadequate network of gauging stations/sites.

In this view, the present study has been conducted to simulate a snowmelt runoff model in an Eastern Himalayan River Basin of India and study the impact of climate change on its runoff regime. For snowmelt runoff modeling, a semi-distributed conceptual model, namely, SNOWMOD has been used on a daily basis. Further, hypothetical climatic scenarios have been used to evaluate the possible impact of climate change on stream flow and its various components in the Subansiri river basin, the study area for the present research work.

\section{The study area and data used}

In the present study, the Subansiri River basin has been taken up as the study area. It is a major north bank tributary of river Brahmaputra. The river originates beyond the Great Himalayan Range (Central Himalaya) at an altitude of around $5340 \mathrm{~m}$.

The total length of the river in the mountainous terrain is about $208 \mathrm{~km}$. The riverbed falls from a height of $4206 \mathrm{~m}$ to $80 \mathrm{~m}$ near Dulangmukh in the foothills. After flowing for about $70 \mathrm{~km}$ from the hills, the river falls in to the KherkutiaSuti and thereafter flowing for another $60 \mathrm{~km}$ it outfalls into the river Brahmaputra. 
Throughout its journey from the central Himalaya to the Arunachal foothills, the Subansiri receives the discharges of numerous mountainous big and small streams. The number of its tributaries is more in the Siwalik foothills than in other zones. The total length of the known and well-defined tributaries of Subansiri is $1960 \mathrm{~km}$.

The region may be divided into four parts; the distant Tibetan mountains beyond the international border, the reach lying between the international boundary and Miri hills of Arunachal Pradesh, the Arunachal Pradesh portion between the outskirt of Miri hills and the interstate boundary of Assam and Arunachal Pradesh and lastly the plains of Assam. The first two belongs to the great Himalayan range, the third belonging to the Sub-Himalayas and the fourth in the fertile plains of Assam. The total catchment area of Subansiri basin is 37000 sq.km, out of which about 14000 sq.km lies in Tibet.

Subansiri basin extends from tropical to temperate zones and therefore the area exhibits a great diversity in rainfall characteristics. In the Northern and Central Himalayan tracts precipitation is scarce on account of high altitudes. Southeast part of the Subansiri basin comprising the sub-Himalayan and the plain tract in Arunachal Pradesh and Assam, lies in the tropics. Precipitation occurs in this region in copious quantities due to Northeast as well as Southwest monsoon. Particularly the Southwest monsoon causes very heavy precipitation in the whole of this region during May to October. July and August are generally the high flood months. The Eastern and Central Himalayas function as a great climate divide. In winter, it serves as a barrier to the intense cold continental air flowing southwards and in monsoon months, the moist rain bearing winds are forced up the mountains to deposit their moisture.

Data used for the present study includes meteorological data (daily rainfall and daily mean temperature), hydrological data (daily streamflow) and remote sensing data (SRTM DEM and MODIS snowcover data products).

Observed daily rainfall data from only two stations in the Indian part (Gerukamukh and Daporizo) have been used. For the Tibetan part, high resolution gridded rainfall data at 0.25 degree grid from APHRODITE has been used. Observed daily maximum and minimum temperature data in the Indian part at Gerukamukh have been used to calculate the daily mean temperature. For upper parts, lapse rate has been used. Discharge data available at the outlet of the basin (Chouldhuaghat) have been used. All the above data was available for a concurrent period of 2000-2003 and 2004-2006 considering a water year from October to September.

The elevation data used in this study is the $90 \mathrm{~m}$ resolution (3-arc SRTM), which consists of a specially modified radar system that flew onboard the Space Shuttle Endeavour during an 11-day mission in February of 2000. All SRTM data are freely available at: http://seamless.usgs.gov/Website/ Seamless/. The SRTM-DEM was downloaded from the USGS ftp site.

For snow cover mapping in Subansiri basin, Moderate Resolution Imaging Spectroradiometer (MODIS) snow cover products (Riggs et al., 2007) from 2000 to 2007 covering the Himalayan range in and around the basin have been used. The snow product used in this study is MODIS/Terra Snow Cover 8-Day L3 Global $500 \mathrm{~m}$ Grid (MOD10A2), Version 5, which is available from 24 February, 2000 onwards. Spatial resolution of MOD10A2 is $500 \times 500 \mathrm{~m}^{2}$ in every 8-day period that begins on the first day of each year and continues to first few days of the next year. This product represents the maximum snow extent in the given 8-day period. The MODIS snow cover product has been ordered free of charge through the Distributed Active Archive Center (DAAC) located at the National Snow and Ice Data Center (NSIDC).

\section{Modeling of snowmelt runoff}

Very limited snowmelt runoff studies have been carried in eastern Himalayan region, and no study has yet been done for Subanbsiri basin even though it has a very huge potential of hydropower development. Therefore, in order to simulate the snowmelt runoff in the Subansiri basin, SNOWMOD, a snowmelt runoff model developed in FORTRAN programming language at the National Institute of Hydrology, Roorkee, India has been applied which uses a temperature index approach of snowmelt computation. It simulates all components of runoff, i.e. snowmelt runoff, rainfall-induced runoff and base flow, using limited data. 
Further, SNOWMOD has been applied to assess the impact of probable hypothetical scenarios of temperature and/or rainfall on the melt characteristics and daily runoff of the Subansiri river basin up to Chouldhuaghat gauging site.

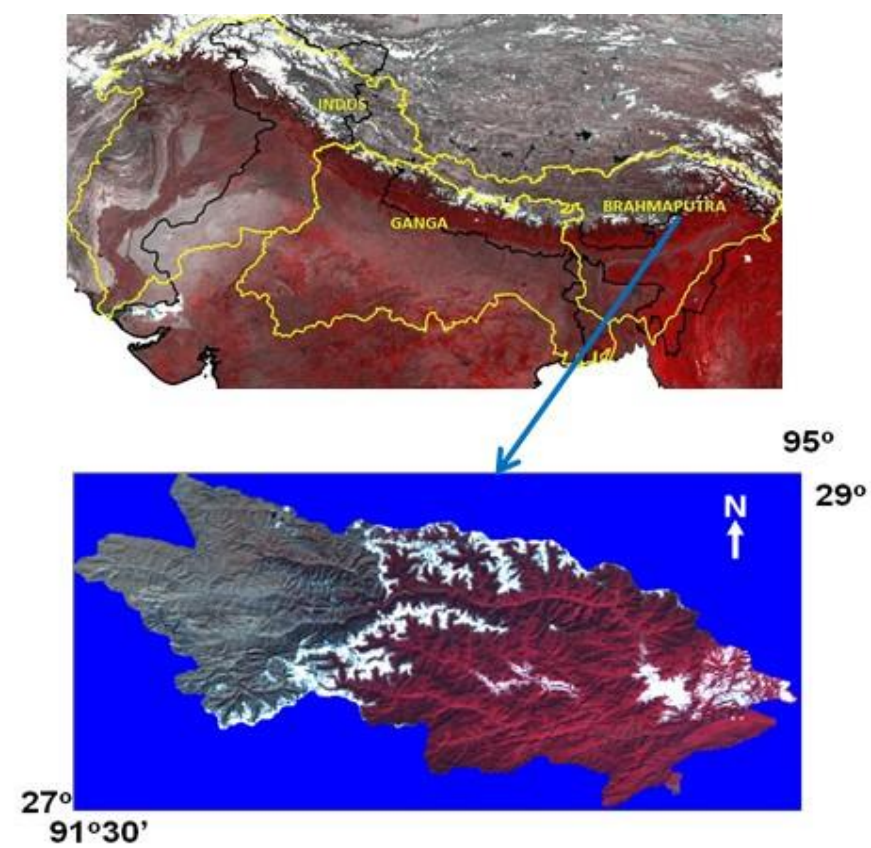

Subansiri River Basin

Figure 1. Study Area

\subsection{Brief description of SNOWMOD}

The snowmelt model (SNOWMOD) is designed to simulate daily streamflow for mountainous basins having contribution from both snowmelt and rainfall. The process of generation of streamflow from such basins involves primarily the determination of the input derived from snowmelt and rain, and its transformation into runoff. For simulating the streamflow, the basin is divided into a number of elevation zones and various hydrological processes relevant to snowmelt and rainfall runoff are evaluated for each zone. The model deals with snowmelt and rainfall runoff by performing the following three operations at each time step: (a) available meteorological data are extrapolated to the different elevation zones, (b) rates of snowmelt and/or rainfall are calculated at different points, and (c) snowmelt runoff from SCA and rainfall runoff from snow free area (SFA) are integrated, and these components are routed separately with proper accounting of baseflow to the outlet of the basin. The model optimizes the parameters used in routing of the snowmelt runoff and rainfall runoff. The structure of the model is shown by means of the flow chart in the following. Details of computation of melt runoff and generation of sreamflow from the basin are given in Singh and Jain (2003).

The input data requirements of SNOWMOD can be divided into three categories i.e. basin characteristics, variables and parameters. SRTM DEM has been used to compute the basin characteristics. The variables include temperature, precipitation and snow covered area. The actual/observed records of temperature and precipitation were available whereas snow cover area has been estimated from satellite imagery. The parameters are temperature lapse rate, critical temperature, degree day factor, runoff coefficient, rainfall contributing area etc. 


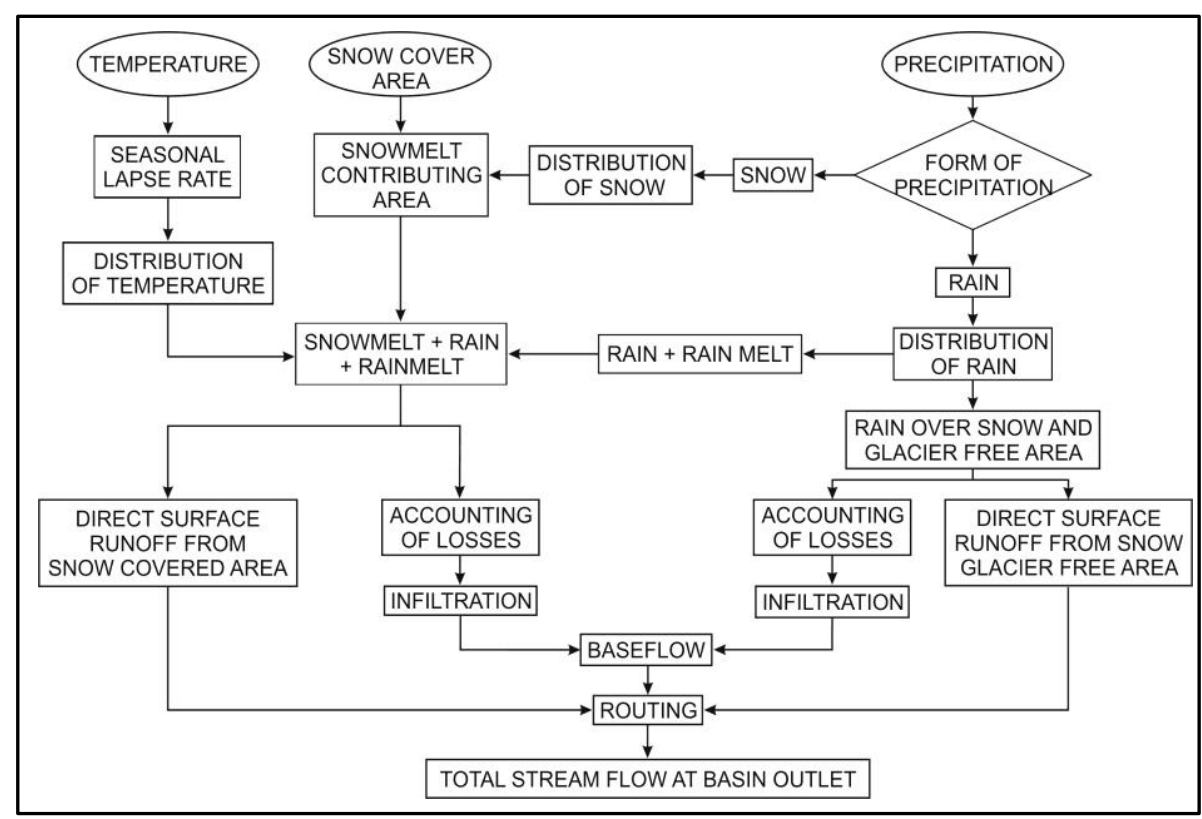

Figure 2. Flow chart of SNOWMOD

\subsection{SNOWMOD Simulation and Estimation of Various Components of Streamflow}

Snow cover area (SCA) is one of the important input variables in SNOWMOD. Snow cover area represents the snowmelt contributing part of the catchment. In the Himalayan basins, conventional methods of measurement have certain limitations due to inaccessibility. As an alternative to field measurements, remote sensing offers the potential of measuring snow covered area measurements in difficult terrain. For snow and ice, satellite data provides information in the Visible, Near Infra Red (NIR), Thermal Infra Red (TIR) and Microwave wavelengths. Further, storage, processing and analysis of the spatial data can be carried out with geographic information system (GIS). Many different instruments on satellites provide continuous information about the earth's actual state. One such instrument, namely, the Moderate Resolution Imaging Spectroradiometer (MODIS) installed on the Terra and Aqua satellites has been extensively used in the recent years for snow cover monitoring. There are two main advantages of the MODIS satellite sensors; one is the high temporal resolution of one day and; second is the high spatial resolution of $500 \mathrm{~m}$ which is available free of cost. Many investigators have carried out comparisons of snow cover images derived from MODIS and other satellite data as well as field based measurements of point snow depth and proved their high accuracy and consistency (Zhaoxia et al., 2007; Wang et al., 2008). As per Hall and Riggs (2007), "the overall absolute accuracy is about 93\%, but varies by land cover type and snow condition".

In the eastern part of the Himalayan region, due to cloud cover it is very difficult to collect cloud free satellite data for most part of the year. The chances of getting cloud-free scenes in the case of MODIS are higher due to higher temporal resolution. Besides, MODIS has an automated snow-mapping algorithm, which reduces the time and errors incorporated during processing satellite data manually. For the present study, snow covered area in the basin has been determined from MODIS in the form of eight day composite snow cover data (MODIS/Terra-MOD10A2 products). Weekly MODIS data have been downloaded and processed for a period of eight years (2000-08) to obtain the SCA depletion curves for the Subansiri basin. The details of MODIS data processing are given in Sarkar (2013). The spatial-temporal variation of SCA in the Subansiri basin is presented in Figure 3 with snow cover area maps of Subansiri basin of different months for the year 2006.

Further, the SRTM-DEM has been used to prepare elevation map of the study area. The basin has been divided into 10 elevation zones with an altitude difference of $600 \mathrm{~m}$. This classified DEM has further been used for the preparation of area-elevation curve. Using the international boundary line given on the Google image of this region, area of the basin falling in Tibet and India have also been calculated for the 
entire 10 elevation zones and shown in Figure 4. However, for the simulation of snowmelt runoff model, area-elevation graph of the whole basin as a whole has been used. The area covered in each elevation zone for the catchment is given in Table 1.

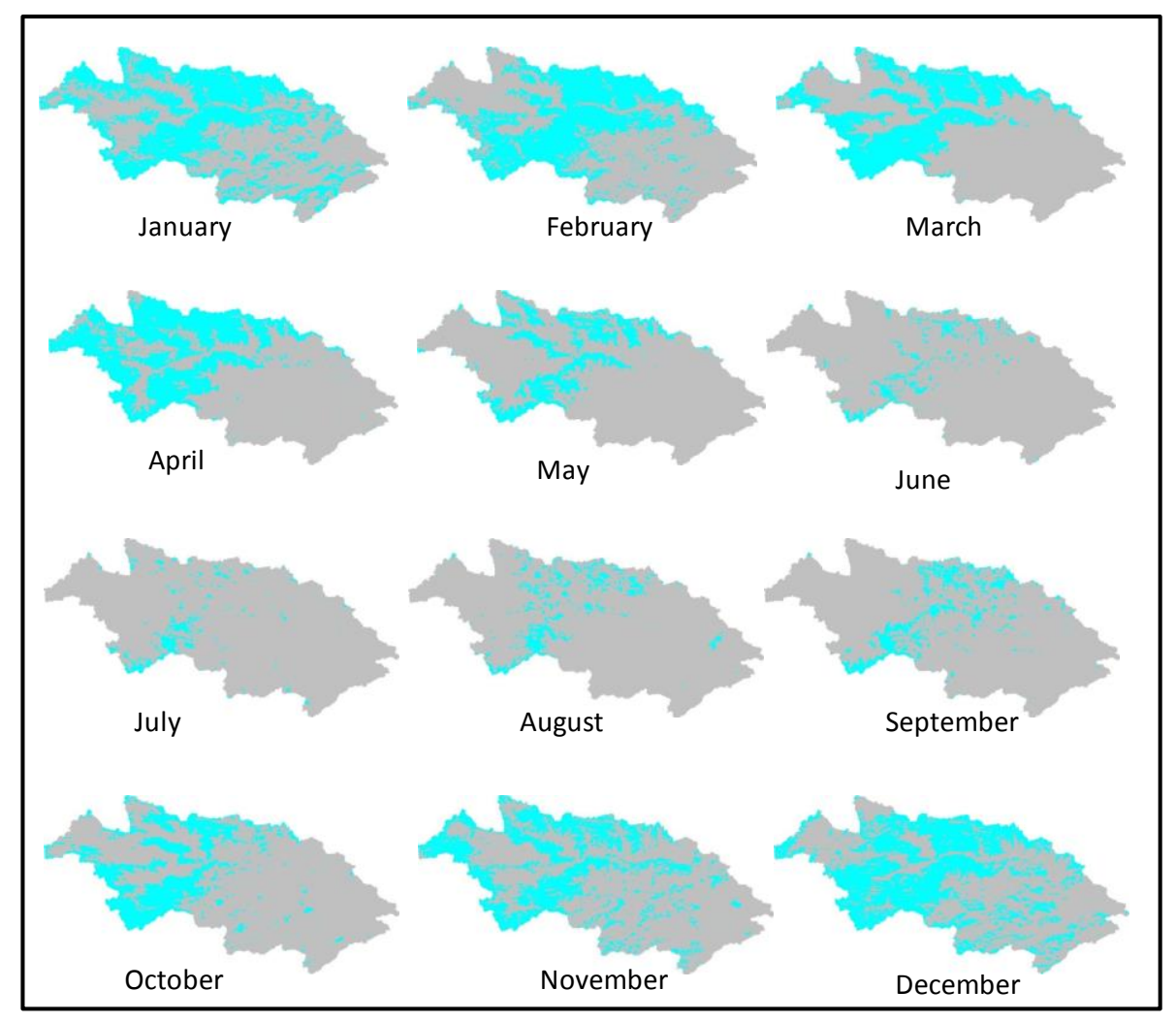

Figure 3. Monthly distribution of SCA in Subansiri basin for the year 2006

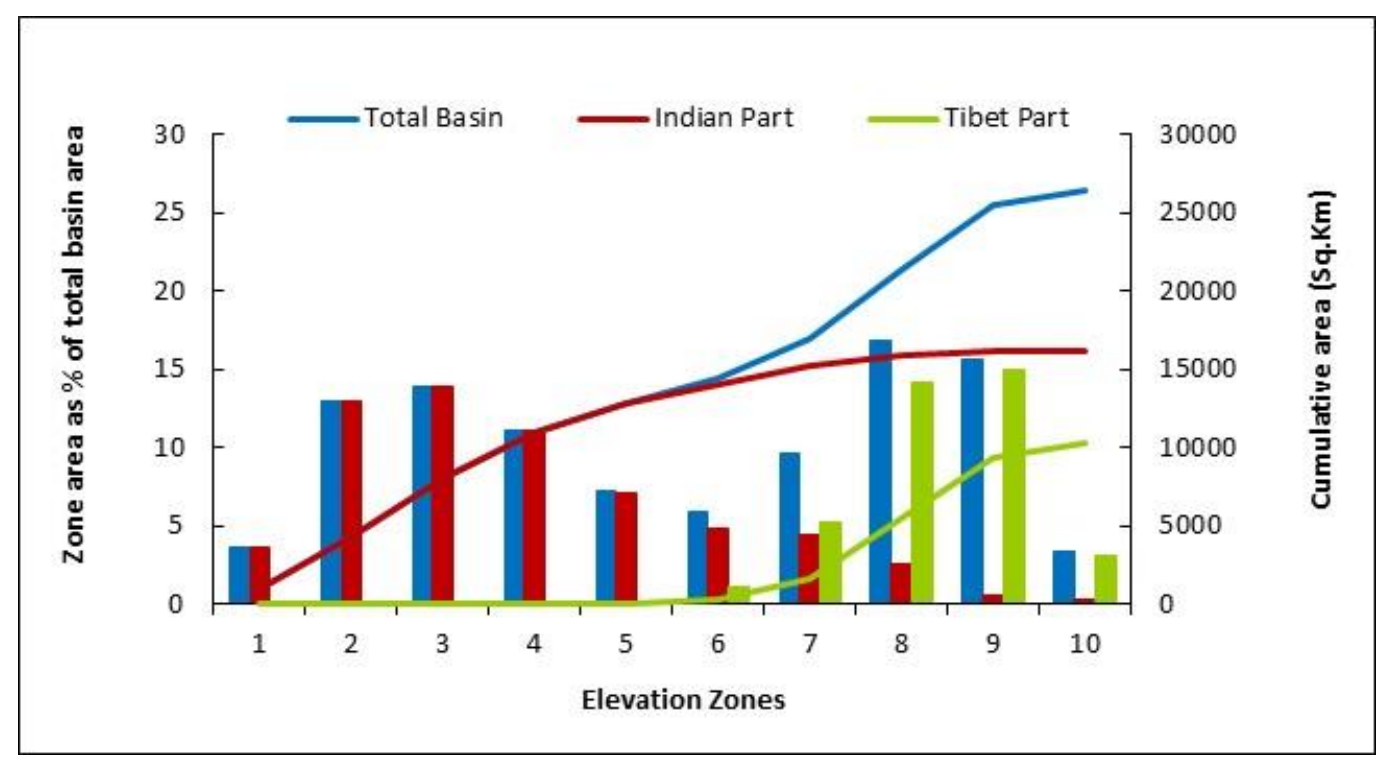

Figure 4. Area-elevation curve of Subansiri basin showing the divided basin area in Tibet and India

For the present study, the daily precipitation data were available for two stations within the study area. These stations are located in lower part of the catchment. For upper part of the catchment (higher elevation zones), rainfall data obtained from APHRODITE water resource project (Yatagai et al., 2012) have been used. The rain gauge/grid data have been considered for different elevation zones (Table 1) based 
on its proximity to the respective elevation zones according to altitude of the station. The daily temperature in various elevation zones has been computed by the temperature lapse rate approach, by extending data from the base station (Gerukamukh) considering seasonally varying lapse rate values ( 0.65 for snow accumulation period \& 0.5 for snow depletion period).

Table 1. Percentage area of Subansiri basin in different elevation zones

\begin{tabular}{c|c|c|c|c|c}
\hline Zone & $\begin{array}{c}\text { Elevation } \\
\text { Range }\end{array}$ & Area $\mathbf{( k m}^{\mathbf{2}} \mathbf{\text { \% Area }}$ & $\begin{array}{c}\text { Raingauge } \\
\text { Station }\end{array}$ & $\begin{array}{c}\text { Temperature } \\
\text { station }\end{array}$ \\
\hline 1 & $<600$ & 949.43 & 3.59 & Gerukamukh & Gerukamukh \\
\hline 2 & $600-1200$ & 3409.56 & 12.91 & Gerukamukh & Gerukamukh \\
\hline 3 & $1200-1800$ & 3659.36 & 13.85 & Daporizo & Gerukamukh \\
\hline 4 & $1800-2400$ & 2919.96 & 11.05 & Daporizo & Gerukamukh \\
\hline 5 & $2400-3000$ & 1913.78 & 7.24 & APHRODITE & Gerukamukh \\
\hline 6 & $3000-3600$ & 1570.967 & 5.95 & APHRODITE & Gerukamukh \\
\hline 7 & $3600-4200$ & 2551.92 & 9.66 & APHRODITE & Gerukamukh \\
\hline 8 & $4200-4800$ & 4427.07 & 16.76 & APHRODITE & Gerukamukh \\
\hline 9 & $4800-5400$ & 4131.66 & 15.64 & APHRODITE & Gerukamukh \\
\hline 10 & $>5400$ & 885.29 & 3.35 & APHRODITE & Gerukamukh \\
\hline
\end{tabular}

With all the input data processed and prepared in the SNOMOD format, the model simulated daily streamflow satisfactorily for all the years except 2003-2004. Due to some gaps in the field data, the year 2003-2004 was not considered for simulation. The model was calibrated using the dataset for a period of three years (2000-2003) and model parameters for stream flow routing were optimized. Using the optimized parameters, the model was validated for a period of three years (2004-2007). Stream flow simulations were also made on yearly basis for the years 2004-2005, 2005-2006 and 2006-2007. From simulations for all the years, it is clear that the volumes and peaks of streamflow have been reproduced well by the model. For all the years, snowmelt runoff and rainfall runoff have been computed separately. The accuracy of the stream flow verification has been determined using three criteria, viz, shape of the outflow hydrograph, efficiency and difference in volume. Efficiency has been computed using nondimensional Nash-Sutcliffe ' $\mathrm{R}^{2 \text { ' }}$ value. For all the years, model successfully simulated the observed flow and efficiency of the model varied between $74-84 \%$. For the three year period i.e. for 2000-2003 and 2004-2007, efficiency varied from $73 \%$ to $79 \%$. In all the years, high flow occurred in the month of July and August. A close observation of rainfall and streamflow data indicates that most of the peaks in the streamflow were because of rainfall. It has been found that annual snowmelt runoff contribution varied from $11-16 \%$ for calibration and validation years. While annual rainfall runoff and base flow contribution varied from $73-79 \%$ and $25-27 \%$ respectively. This kind of information has not yet been reported by any research work so far.

\section{Impact of climate change - application of scenarios}

Climate models, which are mathematical representations of large scale physical processes governing the climate system, have been developed to simulate the present climate and used to predict future climate change. While climate models exhibit significant ability at the hemispherical and continental spatial scales incorporating high complexity of the global system, they are essentially incapable of representing local sub-grid scale features and dynamics (Carter et al., 2000). Because of the coarse resolution and simplified representation of hydrological cycle in climate models, it is not possible to make direct and reliable predictions of regional hydrological changes.

Another approach used in climate change impact studies is based on hypothetical scenarios (Chang, 1999). It is possible to represent a wide range of changed climate scenarios in a simple form through the use of hypothetical scenario approach. Hypothetical scenarios can be employed to assess the sensitivity of a particular basin to altered climatic conditions. Many studies have been reported to have used such altered 
time series to assess possible effects of climate change (Singh and Bengtsson, 2004). The present study considered the following ten scenarios.

$$
\begin{array}{ll}
\mathrm{T}+0, \mathrm{P}+0 \% & \text { (Baseline) } \\
\mathrm{T}+1^{\circ} \mathrm{C}, \mathrm{P}+0 \% & \mathrm{~T}+2^{\circ} \mathrm{C}, \mathrm{P}+0 \% \\
\mathrm{~T}+1^{\circ} \mathrm{C}, \mathrm{P}+5 \% & \mathrm{~T}+2^{\circ} \mathrm{C}, \mathrm{P}+5 \% \\
\mathrm{~T}+1^{\circ} \mathrm{C}, \mathrm{P}+10 \% & \mathrm{~T}+2^{\circ} \mathrm{C}, \mathrm{P}+10 \% \\
\mathrm{~T}+1^{\circ} \mathrm{C}, \mathrm{P}-5 \% & \mathrm{~T}+2^{\circ} \mathrm{C}, \mathrm{P}-5 \% \\
\mathrm{~T}+1^{\circ} \mathrm{C}, \mathrm{P}-10 \% & \mathrm{~T}+2^{\circ} \mathrm{C}, \mathrm{P}-10 \%
\end{array}
$$

SNOWMOD model simulates all the three components of runoff, i.e., snowmelt runoff, rainfall-induced runoff and baseflow. However, it is the snowmelt runoff which shows a significant effect of climate change. Snowmelt is directly related to air temperature and rise in temperature accelerates the melting of snow leading to alterations in the snow cover area. Therefore, it is imperative to use modified snow cover area information (modified SCA depletion curves) as input for stream flow simulation under enhanced temperature scenarios. In the present study, the Subansiri basin uptoChouldhuaghat site has been divided into ten elevation zones out of which seven zones exhibit seasonally varying snow cover. Modified SCA depletion curves were prepared for these seven elevation zones (Sarkar, 2013). For this purpose, a simple linear regression relationship was developed between SCA and average cumulative air temperature as done in many earlier studies, mostly in the western Himalayan region (Tekeli et al., 2005). Using the developed relationship and changed air temperature scenario, the SCA depletion curves were modified.

The SNOWMOD model has been simulated for two sets of data (2000-03\& 2004-07) with input of modified climate data and correspondingly modified SCA for all the ten hypothetical climate change scenarios as described earlier. Based on these simulations, stream flow as well as snowmelt runoff have been computed for all of the hypothetical scenarios. Using the simulated daily flows, mean annual flows and mean snowmelt runoff has been computed using the six years data.

\subsection{Observed Impact of Changed Climate Scenarios on Stream Flow/Snowmelt Runoff}

Based on the above simulations, the simulated daily flows have been used to compute mean annual flows and mean snowmelt runoff with six years data. It has been observed that for all the climate scenarios, mean annual snowmelt runoff (mean of six years daily values) increased and it is mainly due to the temperature rise. The amount of change in snowmelt runoff for a particular climate scenario depicts the mean value of change over the six years period which might be different for different years depending on the climatic conditions over the basin for a particular year. Based on six years projected climatic simulations, the climate scenario with a temperature rise of $2^{\circ} \mathrm{C}$ and precipitation increase of $10 \%\left(\mathrm{~T}+2^{\circ} \mathrm{C}\right.$, $\mathrm{P}+10 \%)$ showed a maximum increase in snowmelt runoff, almost more than $14 \%$. On the other hand, the climate scenario with a temperature rise of $1^{\circ} \mathrm{C}$ and precipitation decline of $10 \%\left(\mathrm{~T}+1^{\circ} \mathrm{C}, \mathrm{P}-10 \%\right)$ showed minimum increase in snowmelt runoff, only about $3 \%$.

The behavior of total stream flow under the influence of various climate change scenarios is different from the snowmelt runoff behavior under similar scenarios. It has been observed that for all the scenarios of increase in temperature as well as increase in precipitation, mean annual stream flow increased. However, for the scenarios of warmer climate and reduced precipitation, the mean annual stream flow decreased. The reason behind this behavior is that this basin is mainly rainfall dominant basin. With climate scenarios of increase in temperature only, the mean annual stream flow increases due to enhanced melting. In case of climate scenarios with increasing temperature as well as precipitation, the mean annual stream flow increases because of enhanced melting as well as the increased rainfall in the basin. On the other hand, with climate scenarios of increased temperature and reduced precipitation, the mean annual stream flow decreases because of the reduction in rainfall as well as the snowpack in the basin. Based on six years projected climatic simulations, the climate scenario with a temperature increase 
of $2^{\circ} \mathrm{C}$ and precipitation increase of $10 \%\left(\mathrm{~T}+2^{\circ} \mathrm{C}, \mathrm{P}+10 \%\right)$ showed a maximum increase in mean annual stream flow by more than $5 \%$, whereas, climate scenario with a temperature increase of $1^{\circ} \mathrm{C}$ and precipitation decrease of $10 \%\left(\mathrm{~T}+1^{\circ} \mathrm{C}, \mathrm{P}-10 \%\right)$ showed a maximum reduction in mean annual stream flow by about $11 \%$.

Further, a seasonal analysis of the total stream flow has been carried out under the influence of the two extreme scenarios which produced maximum increase/decrease in total stream flow of the basin. For this purpose, the whole year was divided into four seasons, namely post-monsoon (October-November), winter (December-February), pre-monsoon (March-May) and monsoon (June-September), similar to the seasonal trend analysis in the previous section. This analysis has been carried out for the year 2006-07 (Figure 5) as it is the most recent year from data availability point of view and also the year registering highest daily discharge among the six years considered for the present study.

The seasonal stream flow analysis considering the scenario of warmer climate and enhanced precipitation $\left(\mathrm{T}+2^{\circ} \mathrm{C}, \mathrm{P}+10 \%\right)$ as shown in Figure 5suggests that the annual water availability is increased marginally with a reduction in water availability during pre-monsoon, winter and post-monsoon seasons, however, there is substantial increase in water availability during monsoon season. In other words, the impact of $\left(\mathrm{T}+2^{\circ} \mathrm{C}, \mathrm{P}+10 \%\right)$ climate will not be severe on total annual stream flow, from a short to medium term context, but it indicates a high impact on the seasonal distribution of stream flow. The reduction of stream flow during pre-monsoon, winter and post-monsoon seasons is alarming, especially in the months of March, April and May because water demand is highest during this period. Reduced water availability in these months may have severe implications on water supply, irrigation and hydropower production. On the contrary, increase in stream flow in the monsoon season will pose an increased risk of floods in the already flood prone basin.

Impact of the other extreme climate scenario of warmer climate and reduced precipitation, i.e., $\left(\mathrm{T}+1^{\circ} \mathrm{C}\right.$, $\mathrm{P}-10 \%)$ as represented by the bar chart in Figure 5demonstrates comparatively significant reduction in annual water availability in the basin with reduction in water availability in all the four seasons. Such reduction in water availability throughout the year coupled with projected increase in population in the coming years (WAPCOS, 2007) might have serious implications on the quantity as well as quality of water supply and pose drought risks in the basin.

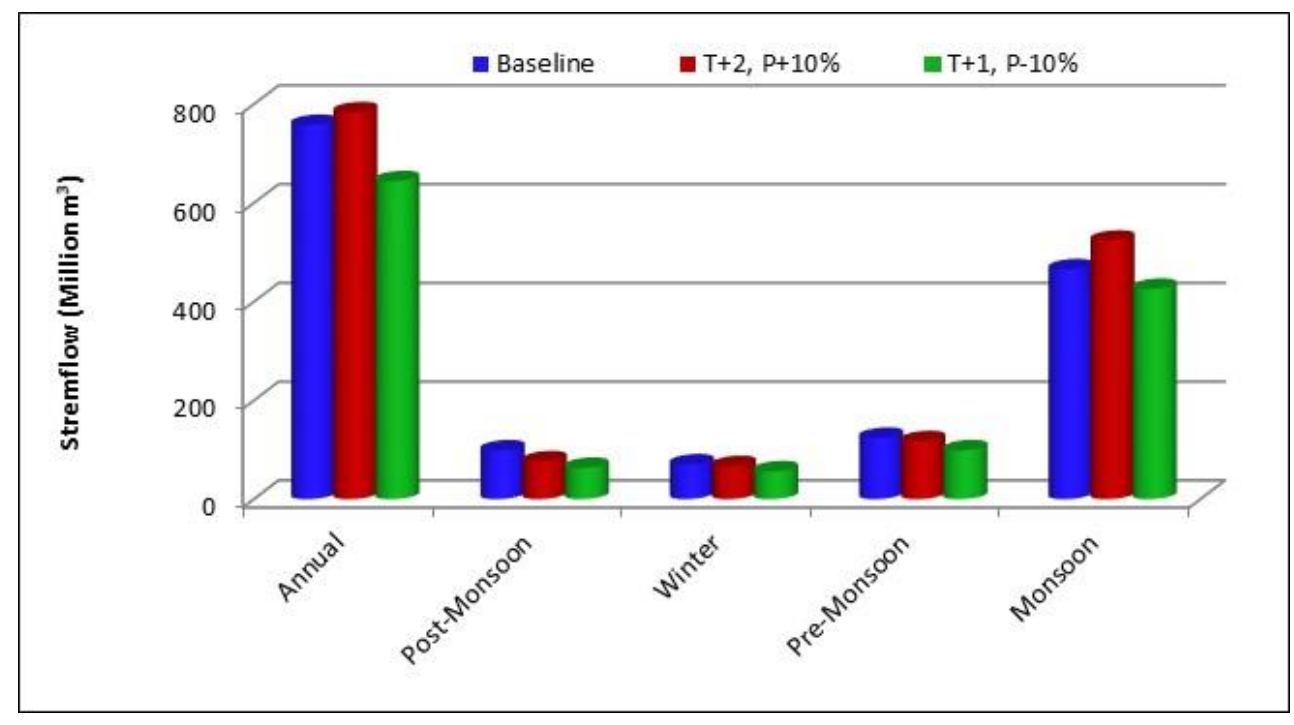

Figure 4. Projected changes in stream flow (baseline 2006-07) for different seasons

\section{Conclusions}

In the present work, first, snowmelt runoff modeling has been carried out for the Subansiri River basin having a complex and diverse hydrometeorology with upper $40 \%$ area in cold arid region of Tibetan 
plateau and lower area joining the floodplains of Assam. The snowmelt runoff model SNOWMOD simulated all the three components of runoff, i.e. snowmelt runoff, rainfall-induced runoff and base flow with limited six years daily data of rainfall, temperature, snow cover area and discharge. The model was calibrated for the study basin using continuous water year data (October-September) of three years (2000-03) and validated for another set of continuous three years data (2004-07).The model efficiency $\left(R^{2}\right)$ varied between 0.73 and 0.79 . Therefore, in spite of the huge catchment area and limited input data for modeling, the results suggest a satisfactory simulation of runoff in the Subansiri basin. It has been found that most of the peaks observed in the stream flow result from rainfall, but prolonged high flows also constitute a component of snowmelt. Further, the modeling results suggest that in the Subansiri basin up to Chouldhuaghat site, about $11-16 \%$ of annual flow is generated from snowmelt, $58 \%$ to $62 \%$ from rainfall and $25 \%$ to $27 \%$ from base flow.

Further, the probable impact of climate change has been analyzed using hypothetical climate change scenarios to understand the behavior of snowmelt runoff and total stream flow of Subansiri basin under the changed climatic conditions. Ten hypothetical scenarios. The climate change impact study has been carried out with data of 2000-2003 and 2004-2007. It has been observed that total stream flow as well as snowmelt runoff increases when temperature is increased. The reason behind this increase is the increased snowmelt runoff which increases because of increased melting of snow with rise in temperature. The observed increase in snowmelt runoff for increase of $1^{\circ} \mathrm{C}$ and $2^{\circ} \mathrm{C}$ in temperature is about $2.5 \%$ and $5 \%$ respectively. However, there is not much change in snowmelt runoff with the changed precipitation scenarios. This study points towards change in total stream flow of Subansiri basin for all the scenarios of temperature and precipitation. The observed maximum percentage increase in mean annual stream flow is about $5 \%$ for $\left(T+2^{\circ} \mathrm{C} \& \mathrm{P}+10 \%\right)$ scenario and the maximum decline in mean annual stream flow observed is about $11 \%$ for $\left(T+1^{\circ} \mathrm{C} \& \mathrm{P}-10 \%\right)$ scenario. This research work presenting the impact of different climate scenarios on the stream flow of Subansiri basin has been carried out for the first time. The results would be very beneficial for planning of upcoming water resources projects in the basin, especially hydropower projects, which will have to be designed keeping in view the magnitude of variability in flows expected due to changing climate conditions. This study is the first of its kind in part of trans-boundary Brahmaputra basin and augurs well for the applicability of the model for other snow-fed sub-basins of the Brahmaputra River.

\section{References}

Borgaonkar H.P. and Pant G.B. (2001), Long term climate variability over Monsoon Asia as revealed by some proxy sources, Mausam, 52(1), 9-22.

Caesar J., Alexander L. and Vose R. (2006), Large- scale changes in observed daily maximum and minimum temperatures: Creation and analysis of a new gridded data set, J. Geophysical Res., 111, D05101, doi:10.1029/2005JD006280.

Carter T.R., Hulme M., Crossley J.F., Malyshev S., New M.G., Schlesinger M.E. and Tuomenvirta H. (2000), "Climate Change in the $21^{\text {st }}$ Century - Interim Characterizations based on the New IPCC Emissions Scenarios," The Finnish Environment 433, Finnish Environment Institute, Helsinki, 148.

Chang Yu- Xu. (1999), Climate change and hydrologic models: A review of existing gaps and recent research developments, Water Resources Management, 13, 369-382.

Dye D.G. (2002), Variability and trends in the annual snow-cover cycle in Northern Hemisphere land areas, 19722000, Hydrologic Processes, 16, 3065-3077.

Hall D.K. and Riggs G.A. (2007), Accuracy assessment of the MODIS snow products, Hydrological Processes, 21, 1534-1547.

IPCC (2007), “Climate Change 2007, The Physical Science Basis, Contribution of Working Group 1," in the Fourth Assessment Report of the Intergovernmental Panel on Climate Change (eds. S. Solomon, D. Qin, M. Manning, Z. Chen, M.C. Marquis, K. Averyt, M. Tignor and H.L. Miller), Intergovernmental Panel on Climate Change, Cambridge and New York. 
IPCC (2013), Summary for Policymakers. In: Climate Change 2013: The Physical Science Basis. Contribution of Working Group I to the Fifth Assessment Report of the Intergovernmental Panel on Climate Change [Stocker, T.F., D. Qin, G.-K. Plattner, M. Tignor, S.K. Allen, J. Boschung, A. Nauels, Y. Xia, V. Bex and P.M. Midgley (eds.)]. Cambridge University Press, Cambridge, United Kingdom and New York, NY, USA.

Riggs G.A., Hall D.K. and Salomonson V.V. (2007), MODIS snow products user guide to collection 5. doi:modis-snowice.gsfc.nasa.gov/sug_c5.pdf.

Sarkar A. (2013), Runoff and Sediment Modeling in part of the Brahmaputra basin. PhD Thesis, Indian Institute of Hydrology, Roorkee, India.

Singh P. and Jain S.K. (2003), Modeling of stream flow and its components for a large Himalayan basin with predominant snowmelt yields, Journal of Hydrological Sciences, 48(2), 257-276.

Singh P. and Bengtsson L. (2004), Hydrological sensitivity of a large Himalayan basin to climate change, Hydrological Processes, 18(13), 2363-2385.

Tekeli A.E., Akyurek Z., Sensoy A., Sorman A.A. and Sorman A.U. (2005), Modeling the temporal variation in snowcovered area derived from satellite images for simulating/forecasting of snowmelt runoff in Turkey, Hydrological Sciences Journal, 50(4), 669-682.

Wang X., Xie H. and Liang T. (2008), Evaluation of MODIS snow cover and cloud mask and its application in Northern Xinjiang, China, Remote Sensing Environ., 112, 1497-1513.

WAPCOS (2007), Environmental and Socio-Economic Baseline Setup, available online at http://sjvn.nic.in/SocietyEnviron/Chap-4\%20revised_4.pdf

Yatagai A., Kamiguchi K., Arakawa O., Hamada A., Yasutomi N. and Kitoh A. (2012), APHRODITE: Constructing a longterm daily gridded precipitation dataset for Asia based on a dense network of rain gauges, Bulletin of American Meteorological Society, doi:10.1175/BAMS-D-11-00122.1.

Zhaoxia Pu, Li Xu and Salomonson V.V. (2007), MODIS/Terra observed seasonal variations of snow cover over the Tibetan Plateau, Geophysical Research Letters, 34, L06706, doi:10.1029/2007GL029262 